\title{
Article
}

\section{Involving Corporate Functions: Who Contributes to Sustainable Development?}

\author{
Stefan Schaltegger *, Dorli Harms, Sarah Elena Windolph and Jacob Hörisch \\ Centre for Sustainability Management, Leuphana University Lüneburg, Scharnhorststr. 1, \\ 21335 Lüneburg, Germany; E-Mails: dharms@uni.leuphana.de (D.H.); \\ windolph@uni.leuphana.de (S.E.W.); hoerisch@uni.leuphana.de (J.H.) \\ * Author to whom correspondence should be addressed; E-Mail: schaltegger@uni.leuphana.de; \\ Tel.: +49-4131-677-2181.
}

Received: 1 April 2014; in revised form: 9 May 2014 / Accepted: 13 May 2014 /

Published: 19 May 2014

\begin{abstract}
A large body of literature claims that corporate sustainable development is a cross-functional challenge, which requires all functional units to be involved. However, it remains uncertain to what extent and in which way different corporate functions are actually involved in corporate sustainability management. To bridge this research gap, our paper draws on a concept of involvement introduced in the field of consumer behavior. Based on this previous research, our paper distinguishes two components of involvement: first, a cognitive-affective component, incorporating being affected by sustainability issues and being supportive of corporate sustainability; and second, a behavioral component, represented by the application of sustainability management tools. We use this concept to empirically analyze the involvement of corporate functions in sustainability management and find considerable differences in large German companies. Whereas public relations and strategic management are heavily involved, finance, accounting and management control appear not to be involved. A multinomial logistic regression shows that the cognitive-affective component significantly influences the behavioral component, with a functional unit being affected influencing the application of tools the most. Building on the model proposed, the paper provides implications on how to increase a functional unit's involvement in sustainability management.
\end{abstract}

Keywords: companies; corporate sustainability; environment; functional unit; Germany; involvement; management tool; sustainability management 


\section{Introduction}

Sustainable development requires the contribution and involvement of many actors. Governments, for example, design the necessary regulations and support sustainability efforts of private households and companies; voters elect governments, and consumers influence companies with their consumption patterns. Companies are important players, as they influence the natural environment and society with their product designs and offers, their production processes, purchasing decisions and their business models. Sustainable development therefore requires companies to get actively involved in shaping and implementing sustainability measures [1-6]. Like sustainability on the societal level, the sustainable development of a company requires the involvement of a variety of company-internal actors, since many challenges of sustainability management demand the contribution of several corporate functions [7-9].

The involvement of all functional units is considered to be necessary to create comprehensive sustainability solutions and to impede sustainability problems from being partially or superficially "solved" or from being shifted back and forth between functional units [10-13]. This implies that all steps of value creation have to be included for sustainability management to become effective [14-16]. Shrivastava and Hart [10] emphasize that cross-functional concepts and practices can be seen as a prerequisite for the integration of sustainability into day-to-day operations, since many sustainability challenges touch several functional units within a company. Gattiker and Carter [17] stress the importance of cross-functional collaboration also for non-routine sustainability challenges [18]. Research and development (R\&D), marketing and production, as well as supply chain-related departments, such as purchasing and logistics, have to be involved to develop and promote new successful sustainable products and services [7-9]. In addition, the involvement of supporting functions, such as strategic planning, public relations (PR), accounting, management control and finance, as well as human resources (HR), is relevant to ensure the strategic embedding of sustainability management, the provision of adequate information and personnel motivation [10,14,19]. In line with these illustrative examples, the literature assigns every corporate function a role in sustainability management.

Nonetheless, management research has so far neglected to empirically analyze to what extent different corporate functions within a company are involved in the management of corporate sustainability. This research gap evokes the following question: To what extent and in which way are different functional units involved in corporate sustainability management, and what increases a functional unit's involvement?

Extant sustainability management literature highlights the importance of involving a variety of actors, using terms, such as "stakeholder involvement" [10,20,21], "employee involvement" [22] and "departmental involvement" [23]. Yet, when investigating the engagement of stakeholders, departments, etc., in sustainability management, involvement is mostly used generically and not precisely defined. In contrast, to investigate the engagement of different corporate functions in sustainability management in more detail, this article draws on a concept of involvement previously introduced in the field of consumer behavior research [24,25]. According to Hansen [24] (p. 32) "the concept of involvement can be useful as a measure of the degree of individual motivation in a particular information-acquisition or choice situation". He states that "variations in involvement reflect the extent to which the individual is more or less motivated toward a specific piece of information, product, or the like" [24] (p. 32). 
For corporate sustainability, we argue that Hansen's [24] understanding of involvement can be transferred to better comprehend a functional unit's motivation for dealing with sustainability issues, such as energy use, emissions and occupational health and safety. Accordingly, we draw on the concept of involvement proposed by Hemetsberger and Pieters [25] in the context of consumer behavior research to empirically analyze the involvement of functional units in sustainability management. This concept distinguishes two components of involvement, a cognitive-affective component (i.e., how much a functional unit is affected by sustainability issues and whether it supports corporate sustainability) and a behavioral component (i.e., to what extent sustainability management is implemented by the application of tools).

In doing so, this paper extends the deliberations on involvement in the research area of consumer behavior to corporate sustainability management and adds new insights into the analysis of the involvement of different functional units. The following section argues that this transition is possible by demonstrating the similarities between the consumer involvement approach and the involvement of functional units in sustainability management. Building on this, the paper develops a model distinguishing levels of the corporate sustainability involvement of functional units. In the next step, this model serves to examine the involvement of functional units in corporate practice based on an empirical analysis of large German companies. The paper concludes with the implications of how to strengthen the contribution of the whole company toward sustainable development.

\section{Involvement of Functional Units in Sustainability Management}

\subsection{The Role of Functional Units in Sustainability Management}

A large body of literature agrees that the sustainable development of a company is an overarching and cross-functional challenge that requires all corporate functions and departments to be involved $[10-13,15,16]$.

The production department, for instance, is responsible for clean production processes and securing compliance with regulatory requirements on safety, air emissions and toxic waste [26,27]. Marketing is challenged to conduct market research on consumer preferences for sustainability attributes and to develop eco-marketing campaigns [28,29], whereas $R \& D$ is frequently seen as a driving force for sustainability innovation [30-32]. Purchasing is expected to deal with issues, such as green procurement [7] and sustainable supply chain management [9], while logistics is expected to reduce carbon emissions and to optimize distribution [33].

In addition to those functional units linked to the company-internal and external supply chain, further units are challenged to undertake supporting activities to bolster the core business. Strategic planning is often ascribed in the sustainability management literature to have a core role in cooperating with top management to develop and employ the company's sustainability strategy [34]. PR and communications can fulfil an important role in sustainability communications, e.g., by designing stakeholder dialogues and sustainability reports $[35,36]$. HR needs to deal with employee and social issues [37,38], whereas finance, accounting and management control should provide management with sustainability-relevant information and performance measures [39-41]. 
In sum, all corporate functions are challenged to contribute to corporate sustainability, no matter whether they engage in company-internal activities or in externally visible measures. However, while in the literature, there may be an agreement on the expected contribution of each functional unit, it is uncertain how the different corporate functions are involved in the actual sustainability management practice and by which means the involvement of currently uninvolved functional units could be increased.

The analysis of the involvement of functional units considers each unit as one entity with its own goals and tasks and characterized by its own subculture and subenvironment [42-45]. For instance, in the context of environmental management, Hoffman [43] argues that functional units differ in how they approach environmental issues, because of their distinct interests and values. These differences may also be demonstrated by their varying use of language and can be ascribed, e.g., to the similar education of people belonging to one functional unit $[43,44]$. The following section discusses to what extent these differences between functional units play a role with their involvement in sustainability management.

\subsection{Components of Sustainability Management Involvement}

Sustainability management can be defined as the systematic integration of environmental and social issues into the conventional management of a company [10,19]. To empirically investigate the degree of involvement of functional units, this paper draws on a model based on the involvement approach previously introduced in consumer behavior research. Specifically, we refer to the approach by Hansen [24], which is complemented by the involvement concept introduced by Hemetsberger and Pieters [25]. Their concept [25] ((p. 276) with reference to Houston and Rothschild [46]) distinguishes a cognitive-affective and a behavioral component. The cognitive-affective component refers to a consumer's perceived relevance of an issue in terms of "being involved with an issue" [25] (p. 276). In the context of a functional unit's involvement in sustainability management, this component is assumed to incorporate two elements, namely the functional unit being affected by sustainability issues and its support for corporate sustainability. The behavioral component refers to how a consumer behaves and engages in terms of "being involved [...] in a behavior" [25] (p. 276). The behavioral involvement of a corporate function is, in this paper, operationalized as a function's application of sustainability management tools. These tools, such as labels in marketing, reports in PR or a suggestion scheme in HR, serve to systematically implement sustainability in corporate practice. The application of sustainability management tools thus indicates that a functional unit engages in tangible sustainability management activities.

In the context of consumer behavior research, Hemetsberger and Pieters [25] show that these two components of involvement are positively related. Thus, it can be expected that this relation is also valid for a functional units' involvement in sustainability management. More precisely, the expectation can be formulated that cognitive-affective involvement (i.e., being affected and being supportive) positively influences the behavioral involvement of functional units (i.e., the application of tools).

We are aware that consumer behavior research refers to consumers and, thus, individuals. Still, we argue that there are similarities in the consumer involvement approach and the approach developed in this paper, which allow us to analyze the involvement of functional units in sustainability management. This argument is based on the understanding that a functional unit, like an individual, can be 
distinguished from other units in terms of motivations, information-acquisition and choice-making (adapted from [24]). Accordingly, the involvement of corporate functions in sustainability management can be defined as the extent to which a function acquires information, makes choices and takes actions related to sustainability, such as reducing material use and emissions, promoting occupational safety and health, designing fair-trade products or improving technologies. Moreover, similar to our proposed adaptation, Lorenzoni et al. [47] have used the concepts of cognitive, affective and behavioral involvement in the context of public engagement for climate change.

For the analysis of a functional unit's level of involvement and to empirically test the interrelation of the cognitive-affective and behavioral components of involvement, the following section explains the two components in more detail and formulates hypotheses.

\subsubsection{Cognitive-Affective Involvement}

Firstly, cognitive-affective involvement can be understood as being affected by a particular issue $[25,46]$. Correspondingly, management literature describes that companies can be affected by environmental and social issues with regard to their operations, their products and market-oriented business activities $[48,49]$. The idea of being affected by sustainability issues is also reflected in Freeman's definition of stakeholders [45,50] as "any group or individual who is affected by or can affect the achievement of an organization's objectives" [51] (p. 46). In line with this argument, Speis and Czymmek [49] elaborate on the significant role of stakeholders, located either in the market, in society or inside the company, with regard to companies affected by environmental issues. Facing stakeholder demands can be a decisive cause or trigger for companies to actively engage in environmental activities, especially if neglecting these demands can lead to sanctioning [45,49].

Following this argument and adopting Freeman's [51] stakeholder definition to the approach of this paper, a functional unit can be affected by sustainability issues raised by stakeholders, such as material, energy and water consumption or child, forced and compulsory labor. In addition, being affected may originate from a functional unit's internal or even intrinsic motivation to deal with the challenges of sustainable development [11,51,52]. Similarly, Hemetsberger and Pieters [25] describe extrinsic and intrinsic goals, as well as beliefs and relationships with others, for instance, as possible sources of consumers' cognitive-affective involvement.

In a nutshell, responding to societal stakeholders, such as non-governmental organizations (NGOs) or the local community, mostly serves to secure legitimacy [20,52-54], whereas being affected by customers is mostly related to securing market share and success [20,53,55]. Internally, top management is one possible driver leading functional units to engage with sustainability. If a corporate function is affected by environmental, social or economic sustainability issues, we define this as the first element of cognitive-affective involvement.

Although being affected is considered important for undertaking sustainability management activities $[48,49]$, it can be argued that it is not sufficient. Therefore, we introduce being supportive, understood as a functional unit's support for sustainability activities, as a second element of cognitive-affective involvement (adapted from Hemetsberger and Pieters [25]) in corporate sustainability management. If a functional unit is supportive, it displays its motivation to get involved in sustainability management by promoting its implementation, e.g., through supporting activities and 
projects in other departments or the overall company. The provision of knowledge or resources and the contribution of experience are only some examples. The reasons for being supportive of sustainability management may be very different. Possible explanations are an intrinsic interest in sustainability-related improvements, the possibility to establish long-term collaborations with other departments or the intention to signal the functional unit's disposition to get involved towards top management $[45,56]$.

With regard to both being affected and being supportive, it can be argued that one functional unit may perceive sustainability challenges differently than other departments, due to its particular goals, tasks, subculture and subenvironment [42-45]. This argument supports the expectation that different functional units are affected by sustainability issues to different extents and that they also support corporate sustainability to different degrees. Examples are sales, production or R\&D, which are established to specifically cope with the demands of the market, the technical-economic subenvironment or the scientific subenvironment [42].

\subsubsection{Behavioral Involvement}

The behavioral component of a functional unit's involvement is based on the understanding that companies can make use of management tools to manage business issues, such as quality or employee participation [57,58]. The wide range of sustainability management tools proposed and discussed in literature [4,55,59] addresses different issues of sustainability: an environmental declaration, for instance, focuses on environmental aspects; continuous education addresses employee and social issues; environmental cost accounting is directed to the economic dimension; whereas a sustainability audit covers the whole range of sustainability aspects and their integration. As sustainability management tools are often applied by functional units, the functional units' involvement within a company is of utmost importance. Several publications document that a range of different practices or tools exist for each functional unit $[4,13,59]$.

For the purpose of this paper, each corporate function was matched with three sustainability management tools widely discussed with respect to the particular functional unit. To do so, we reviewed the literature on management tools applied in functional units (Table 1) and consulted existing matches of tools and units $[4,60]$. Of course, there are more sustainability management tools available, yet we decided to select an identical number of well-documented tools for each functional unit to allow comparing the results of the statistical analysis. Table 1 provides an overview of the matching between each functional unit and three selected typical tools, as well as the according references in the literature. Knowing that the number and nomenclature of the corporate functions may vary depending on the company or the industry and that the tool application may depend on the practicability of the tools, the budget of the functional unit, the expertise, etc., Table 1 is not conclusive, but indicative.

Based on this choice of sustainability management tools, the paper examines the application of tools to assess the behavioral involvement of functional units in the implementation of sustainability management. The following section summarizes the two components of involvement in two hypotheses and a model. 
Table 1. Corporate functions and selection of typical sustainability management tools.

\begin{tabular}{|c|c|c|}
\hline Functional unit & Selection of typical sustainability management tools & Literature \\
\hline \multirow{3}{*}{ Production/R\&D } & Design (eco, sustainable) & \multirow{3}{*}[26,27,30-32]{} \\
\hline & Product carbon footprint & \\
\hline & Eco-efficiency-analysis & \\
\hline \multirow{3}{*}{ Marketing } & Label (eco, social, sustainability) & \multirow{3}{*}[28,29]{} \\
\hline & Sponsoring (eco, social, sustainability) & \\
\hline & Marketing (eco, social, sustainability) & \\
\hline \multirow{3}{*}{ Purchasing/logistics } & Green purchasing & \multirow{3}{*}[7,9,33]{} \\
\hline & Green/sustainable supply chain management & \\
\hline & Material flow analysis/material and energy flow accounting & \\
\hline \multirow{3}{*}{ Strategic planning } & Mission statement (environmental, social, sustainability) & \multirow{3}{*}[34,61]{} \\
\hline & Risk/scenario analysis & \\
\hline & Early detection & \\
\hline \multirow{3}{*}{ PR } & Report (environmental, social, HR, sustainability) & \multirow{3}{*}[35,36]{} \\
\hline & Environmental declaration & \\
\hline & Stakeholder dialogue & \\
\hline \multirow{3}{*}{ HR } & Continuous education & \multirow{3}{*}[37,38]{} \\
\hline & Suggestion scheme & \\
\hline & Employee/corporate volunteering & \\
\hline \multirow{3}{*}{$\begin{array}{l}\text { Corporate } \\
\text { finance/accounting/ } \\
\text { management control }\end{array}$} & Controlling (eco, social, sustainability) & \multirow{3}{*}{ [39-41] } \\
\hline & $\begin{array}{l}\text { Accounting (environmental, material and energy flow, } \\
\text { social, sustainability) }\end{array}$ & \\
\hline & Cost accounting (environmental, material flow, social) & \\
\hline
\end{tabular}

\subsection{Towards an Involvement Model of Functional Units}

To empirically analyze a functional unit's involvement in sustainability management, this paper formulates hypotheses for cognitive-affective (i.e., being affected by sustainability issues and being supportive of corporate sustainability) and behavioral involvement (i.e., the application of sustainability management tools). Similar to the concept of involvement in the context of consumer behavior [25], this paper expects these two components of involvement to be positively related.

\subsubsection{Being Affected by Sustainability Issues and the Application of Tools}

Various studies have shown that companies need to become affected by sustainability issues (e.g., through stakeholder pressure) in order to get actively involved with tangible sustainability measures $[49,54,62,63]$. Transferring these insights to functional units, this paper expects that if a functional unit is affected by sustainability issues, it is more likely to take action and apply appropriate sustainability management tools to address sustainability issues in a systematic manner (e.g., the PR department initiates a stakeholder dialogue with an NGO). Following this argumentation, the first hypothesis is:

H1: Being affected by sustainability issues fosters a functional unit's application of sustainability management tools. 


\subsubsection{Being Supportive of Corporate Sustainability and the Application of Tools}

In addition to being affected, a functional unit may also support the implementation of sustainability in the company with its knowledge, experience and skills, e.g., through the promotion of sustainability measures and projects of other functions and the whole company. This argument emphasizes both the statement that corporate sustainability represents a cross-functional challenge and the rationale that the functional unit's contribution is beneficial for the implementation of sustainability management [13].

Being supportive as an element of involvement in sustainability management becomes effective in the interaction between corporate functions of the company. For example, when the marketing department decides to implement green marketing and to use eco-labels, the R\&D department may support this activity by implementing sustainable design. Similarly, the production can support the marketing endeavors by improving the eco-efficiency of the production processes, applying, e.g., an eco-efficiency analysis.

A functional unit's support for sustainability thus expresses the intensity of motivation (adapted from Hemetsberger and Pieters [25] (p. 276)) and constitutes a second element of cognitive-affective involvement in addition to being affected. This leads to the second hypothesis:

H2: Being supportive of corporate sustainability fosters a functional unit's application of sustainability management tools.

To control for effects that are external to the presented hypotheses, but that may influence a functional unit's application of sustainability management tools, further factors were included in the analysis. Firstly, various authors [27,64] found a significant impact of a company's core business or industry on its sustainability-related behavior (e.g., the introduction of an environmental management system, abatement activities or the choice of sustainability strategies). For instance, Frondel et al. [27] demonstrate that companies from the chemical or minerals industries tend to undertake abatement activities more frequently than companies belonging to other industries. Thus, to control for the influence of industry affiliation, all companies included in our analyses were asked to describe their core business, which was then categorized according to the companies' main sustainability challenges. Four clusters were distinguished (manufacturing, capital goods industry and construction; consumer goods, trade and logistics; finance and services; commodities, auxiliary materials, energy, chemical and pharmaceutical industry).

Additionally, company size may influence the sustainability engagement of a company, since larger companies usually experience more external pressures and possess more resources to deal with sustainability issues [65-67]. As numerous studies indeed reveal the positive effects of company size on single aspects of corporate sustainability management $[27,64,68]$, the covariate "revenue" was also considered in our analysis.

Similarly, it is frequently argued that publicly-owned companies experience more external pressure due to a higher degree of public exposure $[65,66]$. Additionally, certain incentives motivating companies to pursue sustainability management can be identified which only impact stock index listed companies, such as the opportunity to be included in prestigious sustainability indices, like the Dow Jones Sustainability Index [69-71]. To control for the effect of being listed in well-known stock indices, 
another dummy variable was introduced indicating whether or not a company belongs to either the DAX or the MDAX, the two major German stock indices.

Lastly, it can be expected that sustainability management tools, which are more established, as they have existed for many years and have been widely discussed for a longer period, are more likely to be applied. Thus, to avoid distortions caused by differences in the degree that sustainability management tools are established, the age of sustainability management tools was also included as a control variable.

In sum, the proposed links between the two components of involvement, as well as the other factors of potential influence, are displayed in Figure 1 and will be analyzed in Section 4.

Figure 1. Components of a functional unit's involvement in sustainability management.

\begin{tabular}{|c|c|c|}
\hline \multicolumn{2}{|c|}{ Cognitive-Affective Component } & \multirow[b]{2}{*}{ Control Variables } \\
\hline \multirow{3}{*}{$\begin{array}{l}\text { The corporate } \\
\text { function is affected } \\
\text { by sustainability } \\
\text { issues }\end{array}$} & \multirow{3}{*}{$\begin{array}{l}\text { The corporate } \\
\text { function is } \\
\text { supportive of } \\
\text { corporate } \\
\text { sustainability }\end{array}$} & \\
\hline & & Core business \\
\hline & & Company size \\
\hline & & Stock index listing \\
\hline Behaviouı & Component & $\begin{array}{l}\text { Average age of } \\
\text { sustainability }\end{array}$ \\
\hline $\begin{array}{l}\text { The corporate functi } \\
\text { management tools. }\end{array}$ & applies sustainability & management tools \\
\hline
\end{tabular}

\section{Research Design}

\subsection{Methodology and Sample}

The research findings presented in Section 4 are based on an empirical survey carried out between November, 2009, and February, 2010, among the largest German companies by revenue (according to the German newspaper, Welt online [72]; see Tables 2-4 for the sample characteristics). The study focuses on large German companies for several reasons. Firstly, large companies are publically exposed, which may drive them to engage with sustainability more strongly than small and medium-sized enterprises $[65,66]$. Secondly, large companies can be expected to have the resources to inform themselves about sustainability management tools and to apply them on a large scale, e.g., in different departments, divisions, etc. [67,73,74]. Thirdly, a large company has a major impact on environmental and social issues. The contribution of large firms is thus of vital importance if significant contributions to sustainable development are to be achieved. By focusing on one country, the study, fourthly, excludes influences related to contingencies that some corporate sustainability management tools may be regulated or promoted more in one country than in another [75-77].

The contact persons for the survey were managers in charge of sustainability issues, like the chief sustainability managers, because they are expected to have a good overview of who is affected by corporate sustainability and who supports its implementation. Furthermore, the sustainability managers are expected to have good insight into the engagement of all departments, since they interact with 
many different corporate functions to implement sustainability management in the company. To reduce the probability of strategic or the evasive responses of the corporate functions, they were not contacted directly $[2,78]$.

Table 2. Annual turnover/total assets/gross premiums of the companies surveyed.

\begin{tabular}{lll}
\hline $\begin{array}{l}\text { Annual turnover/total assets/ } \\
\text { gross premiums (in million Euros) }\end{array}$ & Frequency & Percentage \\
\hline $0-50$ & 0 & $0 \%$ \\
$>50-500$ & 12 & $11.0 \%$ \\
$>500-1500$ & 18 & $16.5 \%$ \\
$>1500-2500$ & 24 & $22.0 \%$ \\
$>2500-5000$ & 16 & $14.7 \%$ \\
$>5000-50,000$ & 17 & $15.6 \%$ \\
$>50,000$ & 19 & $17.4 \%$ \\
No answer & 3 & $2.8 \%$ \\
Total & 109 & $100.0 \%$ \\
\hline
\end{tabular}

Table 3. Number of employees of the companies surveyed.

\begin{tabular}{lll}
\hline Number of employees & Frequency & Percentage \\
\hline $0-50$ & 0 & $0 \%$ \\
$51-250$ & 1 & $0.9 \%$ \\
$251-1000$ & 12 & $11.0 \%$ \\
$1001-10,000$ & 55 & $50.5 \%$ \\
$10,001-100,000$ & 31 & $28.4 \%$ \\
$>100,000$ & 10 & $9.2 \%$ \\
Total & 109 & $100.0 \%$ \\
\hline
\end{tabular}

Table 4. Core business of the companies surveyed.

\begin{tabular}{lcc}
\hline \multicolumn{1}{c}{ Industry } & Frequency & Percentage \\
\hline Manufacturing, capital goods industry and construction & 24 & $22.0 \%$ \\
\hline Consumer goods, trade and logistics & 33 & $30.3 \%$ \\
\hline Finance and services & 32 & $29.4 \%$ \\
\hline $\begin{array}{l}\text { Commodities, auxiliary materials, energy, } \\
\text { chemical and pharmaceutical industry }\end{array}$ & 20 & $18.3 \%$ \\
\hline
\end{tabular}

The corporate sustainability managers were contacted by phone and asked to fill in a questionnaire sent to them by email or mail. 331 questionnaires were sent out, and the response rate was $32.9 \%$ $(n=109)$. The respondents were mostly sustainability, environmental, health and safety (EHS) or corporate social responsibility (CSR) managers (53.2\%) or, to a lesser extent, associated with PR or communications $(28.4 \%)$, in case the main contact persons for corporate sustainability issues were based in this unit. The remaining $18.3 \%$ either belonged to other functional units $(16.5 \%)$, such as corporate development, or did not reveal their departmental affiliation (1.8\%). To validate the survey, a pre-test was conducted. The data was analyzed using SPSS Statistics 20. 
The questionnaire, inter alia, offered a set of functional units (to measure to what extent they are affected by sustainability issues and whether they support corporate sustainability) and a list of 79 sustainability management tools (to assess the application of these tools) drawn from a review of contemporary sustainability management literature, as discussed above (for an overview, see [4]). In this paper, we limit our analysis to three typical sustainability management tools per functional unit (see Section 2.2.2).

\subsection{Measures}

\subsubsection{Elements of Involvement}

To measure the degree that a functional unit is affected by sustainability issues, the respondents were asked to what extent they perceive the different corporate functions to be affected by environmental and social issues, evaluated on a five-point semantic differential scale. To measure whether the functional unit is supportive of corporate sustainability, the respondents were asked to assess, for each unit, whether it supports the implementation of corporate sustainability. To quantify behavioral involvement, the representatives were asked which sustainability management tools are applied in their company. Based on the matching of corporate functions with three typical sustainability management tools (Table 1), the values for the application of tools range from 0 to 3 . Within the analysis the following, three types of application of tools are distinguished:

- No application: the functional unit does not apply any of the selected tools (0 tools).

- Partial application: the functional unit applies some, but not all of the selected tools (1-2 tools).

- Comprehensive application: the functional unit applies all of the selected tools ( 3 tools).

\subsubsection{Control Variables}

To capture the effects external to the hypotheses presented, the participating companies were asked to describe their core business. In a second step, four clusters were distinguished ( 1 = manufacturing, capital goods industry and construction; 2 = consumer goods, trade and logistics; 3 = finance and services; 4 = commodities, auxiliary materials, energy, chemical and pharmaceutical industry). Moreover, company size was controlled on the basis of the annual revenue published in the Top 500 database of Welt online [58], which was also used for the selection of companies. The third control variable covers the effect of being listed on the stock index. We researched whether the companies participating in the survey were listed in the DAX or the MDAX while the survey was carried out. To do so, we benefited from the data on the index compositions offered on the website of the DAX indices [79]. To consider the age of sustainability management tools (i.e., how many years it has been discussed in the literature), the library service databases, Ebsco [80], and the Web of Science [81] were checked for when each tool was mentioned in academic literature for the first time. 


\section{Empirical Results and Analysis}

\subsection{Varying Involvement of Different Corporate Functions}

The model is based on the argument that the involvement of functional units encompasses being affected by sustainability, being supportive of corporate sustainability and the application of specific sustainability management tools.

Figure 2 shows for several functional units the average extent to which they are affected on a range from 1 to 5 (where 1 means not at all affected and 5 means completely affected).

Figure 2. Functional units' being affected by sustainability issues.

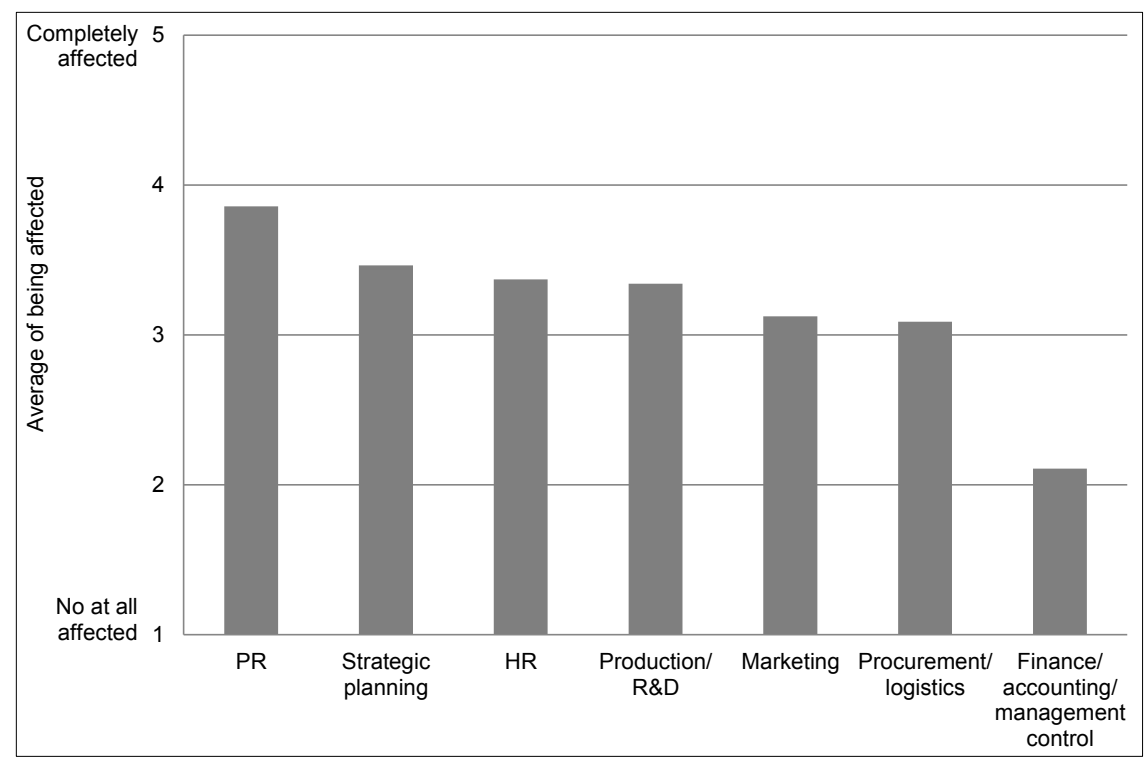

Based on the question: "To what extent are the following organizational units of your company affected by environmental/social/societal issues?"

With regard to the first element of involvement, all functional units seem to be affected by sustainability issues to a certain degree (Figure 2). Nevertheless, substantial differences between the functional units exist. PR, for instance, is perceived to be most strongly affected by sustainability issues, whereas finance, accounting and management control are affected only to a much smaller degree. All other functions can be found in the middle of the scale, ranging from 3.1 on average (procurement/logistics) to 3.5 (strategic planning).

Compared to the evaluation of the extent to which they are affected, even bigger differences can be found for the corporate functions' support for corporate sustainability (Figure 3): the functions that support corporate sustainability most are PR (89.0\% of all companies) and strategic planning (78.9\%), while finance, accounting and management control are supportive in only $7.3 \%$ of all companies. In contrast to the extent of being affected, where HR ranks third, this corporate function is perceived to be among the least supportive units. 
Figure 3. Functional units' being supportive of corporate sustainability.

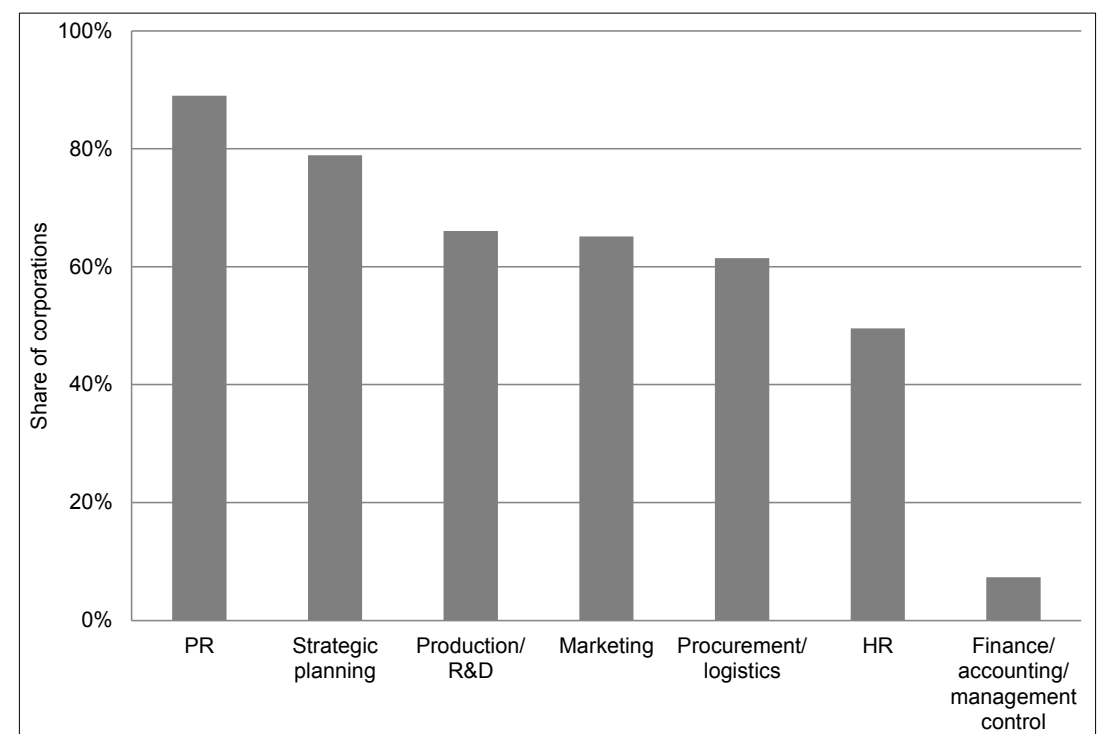

Based on the question: "Which of the following functional units have a supporting influence on the implementation of sustainability in your company?"

Finally, similar differences between functional units exist for the average application of sustainability management tools (Figure 4). This result provides the first hints on the explanatory power of the model. Whereas PR and strategic planning apply 2.0 of the three specific tools on average, only 0.8 and 0.9 tools are applied in production/R\&D and finance, accounting and management control on average. As is the case for the extent of being affected (Figure 3), purchasing and logistics (1.0), HR (1.3) and marketing (1.3) occupy moderate positions (Figure 4).

Figure 4. Application of sustainability management tools by corporate functions.

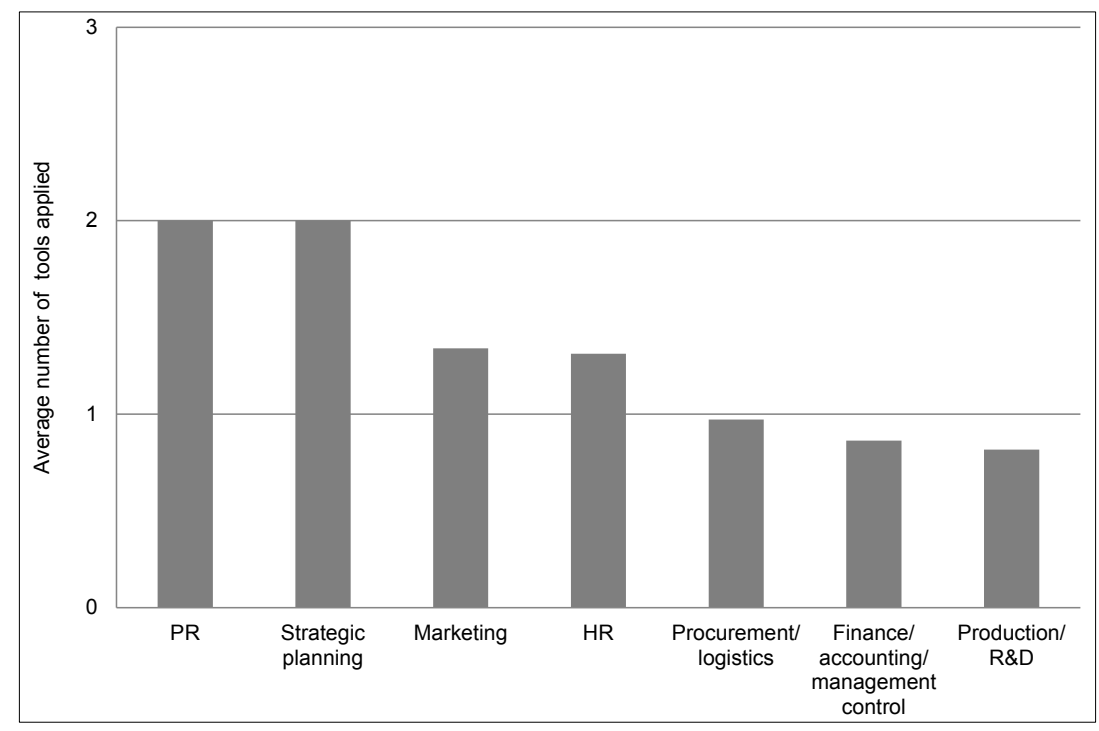

Based on the question "Which sustainability management tools are applied in your company?" For the assignment of tools to corporate functions, see Table 1.

It could be argued, however, that the results are distorted to a certain degree, because some of the survey respondents were associated with PR or communications. To test whether this causes the 
above-average evaluation of the PR department, a $t$-test was performed. This test compares the extent that PR is affected by sustainability issues as evaluated by sustainability managers belonging to that unit with the evaluations of sustainability managers not belonging to the PR department. As Table 5 displays, the difference of the mean is small (3.95 compared to 3.85) and clearly not significant (0.561). Thus, no significant influence of the respondents' affiliation could be identified.

Table 5. Influence of departmental affiliation.

\begin{tabular}{lccccc}
\hline $\begin{array}{l}\text { PR's being affected } \\
\text { as evaluated by } \\
\text { sustainability managers in: }\end{array}$ & N & Mean & T & Significance & $\begin{array}{c}\text { Difference } \\
\text { in means }\end{array}$ \\
\hline the PR unit & 30 & 3.95 & -0.584 & 0.561 & -0.100 \\
\hline other functional unit & 70 & 3.85 & & & \\
\hline
\end{tabular}

\subsection{Being Affected, Being Supportive and Their Effects on the Application of Tools}

To analyze whether being affected by sustainability issues and being supportive of corporate sustainability are related to a functional unit's application of sustainability management tools, first, the direct effects of such an influence were tested. Since being supportive was measured as a dichotomous variable, only the coefficient of contingency and the eta coefficient could be used to assess its statistical connection to the application of sustainability management tools (AT), which is operationalized as the number of selected tools applied by a specific unit (ratio scale). Being affected, however, was measured using a five-point semantic differential scale. It can thus be treated as interval-scaled [82]. Therefore, the product moment correlation coefficient by Pearson can be used in addition to the coefficient of contingency and the eta coefficient to assess the connection between being affected and the application of tools. The coefficient of contingency and the eta coefficient for both variables are displayed to enable a comparison of the strengths of the effects.

As shown in Table 6, both being affected and being supportive are significantly connected with the application of tools. The eta coefficients, as well as a more detailed analysis of the contingency table suggest that being affected and being supportive indeed stimulate the application of sustainability management tools. Since the coefficient for being affected is higher than for being supportive, it can be assumed that the former has a somewhat stronger positive effect on the application of tools.

Table 6. The effects of being affected and being supportive on the application of tools.

\begin{tabular}{lrcc}
\hline Influencing variables (IV) & $\mathbf{C}(\mathbf{I V} * \mathbf{A T})$ & ${\text { Eta coefficient }\left(\mathbf{E t a}^{2}\right)}$ & r (Pearson) \\
\hline Being affected & $0.393 * * *$ & $0.353(0.124)$ & $0.313 * * *$ \\
Being supportive & $0.257 * * *$ & $0.252(0.064)$ & - \\
\hline
\end{tabular}

$\mathrm{C}\left(\mathrm{IV}^{*} \mathrm{AT}\right)$ : coefficient of contingency of the influencing variable and the number of applied tools (AT).

$* * * 1 \%$ level of significance $(p<1 \%)$.

Additionally, since being affected and being supportive may be interrelated, as well, their relationship was tested. Again, since being supportive was operationalized on a nominal scale, no product moment correlation coefficient can be calculated. Instead, the coefficient of contingency was used. With a coefficient of contingency of $0.466(p<1 \%)$, the results demonstrate that a highly 
significant relation between these two factors exists, but still, more than half of the variance cannot be explained by this relationship.

Since the contingency coefficient between being affected and being supportive is only of intermediate strength, a further analysis testing the combined effect of being affected and being supportive on the application of tools can be performed. For the dependent variable, i.e., the application of sustainability management tools, functional units that apply all (three) of the selected tools were distinguished from those units that do not apply any tools and those that apply only some (i.e., one or two) tools. Thus, the dependent variable is measured on an ordinal scale, which is why a multinomial logistic regression needs to be performed. To control for effects, which are external to the hypotheses presented, but are expected to influence a functional unit's application of sustainability management tools, the covariates "core business", "revenue", "stock index listing" and "average age of tools" were included in the analysis (Table 7).

To include the variable "core business", for each of the four categories presented in Section 3.2.2, a separate dummy variable was set up, differentiating companies that belong to the respective group from companies that do not. Similarly, the dummy variable "stock index listing" was included in the model to segregate companies listed in the DAX or MDAX stock indices from other companies.

The category "comprehensive application" of sustainability management tools (i.e., the application of all three typical tools) was used as a category of reference for the multinomial logistic regression. The regression coefficients (B) thus describe the influence of each variable on the probability of belonging to the respective group (no application or partial application) compared to the probability of belonging to the group "comprehensive application". Lastly, the control variable "revenue" was included as a metric variable.

Based on the results of the multinomial logistic regression, the existence of the above-mentioned effects can be confirmed. The highly significant likelihood quotients suggest that both being affected and being supportive influence the application of sustainability management tools. Similarly, significant effects can be identified for the control variables, core business and age of tools. However, the effect size of the latter is very small $(-0.020$ and -0.007$)$ and only significant for the group of "no application". Finally, no statistically significant influence of the companies' revenues or of being listed in a stock index on a functional unit's application of tools could be identified. However, since the sample only contains the largest German companies, the differences in size may not be as pronounced as they might have been had also medium or small-sized companies been taken into account.

As the highly significant negative regression coefficients (B) of being affected demonstrate (Table 7), a functional unit that is affected by sustainability issues to a high degree is less likely to belong to the category of units that apply no or only some sustainability management tools. Since the coefficient for no application is even stronger $(-0.777 ; p<1 \%)$ than that of partial application $(-0.421 ; p<1 \%)$, using comprehensive application as the reference category, functional units with high levels of being affected are most unlikely to belong to the group of no application of sustainability management tools.

As expected, the analysis suggests that functional units that are not supporting corporate sustainability are less likely to apply sustainability management tools. The positive regression-coefficients for the cases of no application $(0.720 ; p<1 \%)$ and partial application $(0.444 ; p<10 \%)$ demonstrate that if a functional unit is not supportive $(\mathrm{S}=0)$, it is unlikely to be involved in the application of sustainability management tools, but most likely to belong to the group of no application. 
The difference in strength between the regression coefficients of being affected and being supportive, as well as the contingency coefficients displayed in Table 6 provide an insight into the size of the effects if both variables are taken into account. The higher coefficients of being affected reveal that it has a stronger influence on the application of tools than being supportive. Taken together, the results confirm hypotheses $\mathrm{H} 1$ and $\mathrm{H} 2$.

Table 7. Multinomial logistic regression.

\begin{tabular}{|c|c|c|c|}
\hline \multicolumn{4}{|l|}{ Test of likelihood quotients } \\
\hline & Independent variable & $(\mathrm{Chi})^{2}$ & Significance \\
\hline & AF (being affected) & $31.408 * * *$ & 0.000 \\
\hline & $\mathrm{S}$ (being supportive) & $7.015 * *$ & 0.030 \\
\hline & Core business & $13.978 * *$ & 0.030 \\
\hline & Revenue & 2.091 & 0.352 \\
\hline & Stock index listing & 2.121 & 0.346 \\
\hline & Age of tools & $8.025 * *$ & 0.018 \\
\hline \multicolumn{4}{|l|}{ Parametric rating } \\
\hline Categories of dependent variable & Independent variable & B & Significance \\
\hline \multirow{10}{*}{ No application of typical tools } & Constant term & $2.252 * * *$ & 0.000 \\
\hline & AF (being affected) & $-0.777 * * *$ & 0.000 \\
\hline & $\mathrm{S}$ (being supportive) ${ }^{\mathrm{a}}$ & $0.720 * * *$ & 0.009 \\
\hline & Core business $=1$ & $0.842 * *$ & 0.013 \\
\hline & Core business $=2$ & $0.537 *$ & 0.098 \\
\hline & Core business $=3$ & 0.007 & 0.984 \\
\hline & Core business $=4^{b}$ & 0 & \\
\hline & Revenue & 0.000 & 0.179 \\
\hline & Stock index listing ${ }^{a}$ & 0.358 & 0.166 \\
\hline & Age of tools & $-0.020 * * *$ & 0.006 \\
\hline \multirow{10}{*}{ Partial application of typical tools } & Constant term & $1.362 * *$ & 0.014 \\
\hline & AF (being affected) & $-0.421 * * *$ & 0.001 \\
\hline & $\mathrm{S}$ (being supportive) ${ }^{\mathrm{a}}$ & $0.444 *$ & 0.073 \\
\hline & Core business $=1$ & $0.576 *$ & 0.054 \\
\hline & Core business $=2$ & $0.683 * *$ & 0.014 \\
\hline & Core business $=3$ & 0.415 & 0.180 \\
\hline & Core business $=4^{b}$ & 0 & \\
\hline & Revenue & 0.000 & 0.700 \\
\hline & Stock index listing ${ }^{a}$ & 0.252 & 0.252 \\
\hline & Age of tools & -0.007 & 0.240 \\
\hline
\end{tabular}

Category of reference: comprehensive application of typical tools; number of observations: 654; pseudo $\mathrm{R}^{2}$ (Nagelkerke): $0.169 ;{ }^{\mathrm{a}} \mathrm{S}$ and stock index listing are dummy variables. The effects of $\mathrm{S}=0$ (not being supportive) and of being listed are tested. ${ }^{\mathrm{b}}$ This parameter is set to zero, as it is redundant. $* * * 1 \%$ level of significance; ** 5\% level of significance; * $10 \%$ level of significance.

\section{Discussion}

Based on the view that corporate sustainability as a cross-functional challenge requires the involvement of all corporate functions, this paper investigates who is involved in corporate 
sustainability management. To operationalize the empirical examination of this question, the involvement approach of Hemetsberger and Pieters [25] used in consumer behavior research was adopted to distinguish two components of the involvement of corporate functions. Firstly, cognitive-affective involvement was measured through being affected by sustainability issues, expressing the relevance of an issue, and through being supportive of corporate sustainability, expressing the intensity of motivation to contribute to sustainability. Secondly, behavioral involvement in sustainability management was measured on the basis of the application of a set of function-specific sustainability management tools. The analysis demonstrates that both being affected and being supportive foster the application of sustainability management tools by a functional unit and, thus, their involvement in sustainability management.

The analysis furthermore shows large differences between the involvement of different corporate functions in sustainability management. In particular, the involvement is highest for PR/communications, while finance, accounting and management control show the lowest involvement. Yet, the data also reveals an important role for strategic planning when it comes to corporate sustainability. For all three aspects of involvement analyzed-i.e., being affected by sustainability issues, being supportive of corporate sustainability and the application of tools - the strategic planning unit ranks second behind the PR department. This could indicate an on-going process in companies: not only is sustainability a corporate communication task, but it is also of strategic relevance. This gives reason to expect a stronger implementation of corporate sustainability in more performance-oriented functional units, such as production and purchasing in the future.

In order to increase the involvement of corporate functions in sustainability management, being affected and being supportive may be useful starting points. Both the extent that functional units are affected and their support for corporate sustainability may be increased through, e.g., awareness programs, information campaigns or an increased strategic relevance of sustainability for top management. The data suggests that an increase in the extent to which functional units are affected is even slightly more effective to foster corporate sustainability than an increase of their support for corporate sustainability.

\section{Conclusions}

Companies are challenged and have the potential to significantly contribute to sustainable development. Sustainability management literature argues that the involvement of all functional units is important to realize this potential and especially to master non-routine sustainability tasks, which usually pose cross-functional challenges $[11,13,19,83]$.

This paper adapted a model to capture the involvement of different functional units based on findings from consumer behavior research. The paper analyzed two components of involvement, i.e., cognitive-affective and behavioral involvement. Original data from 109 large Germany companies clearly shows that externally-oriented departments, like PR and communications, are most involved, whereas internal, performance-oriented units, like finance, accounting and management control, are (nearly fully) excluded. These findings reveal a gap between the status quo in practice and the demands formulated in academia to handle corporate sustainability as a cross-functional challenge. Furthermore, the results indicate that large German companies are mainly concerned with securing 
their reputation and legitimacy through sustainability management and less with their actual sustainability performance. However, keeping in mind that accounting and management control design and manage core information systems for managers and that they serve as links between top management and other corporate functions, a stronger involvement of these functional units is highly recommended.

\section{Acknowledgments}

The authors would like to thank two anonymous reviewers for their valuable feedback. We are furthermore grateful for the feedback we received by the participants of the 3rd International Sustainability Conference 2012 in Basel. Our research also benefited from the financial support of PwC (PricewaterhouseCoopers) Germany for the "Corporate Sustainability Barometer" 2009/2010. Lastly, for his very valuable support in the literature search on the age of sustainability management tools, we are very thankful for the support of Joscha Enger.

\section{Author Contributions}

Stefan Schaltegger: conception of the research approach; data interpretation; writing. Dorli Harms: conception of the research approach; literature review; data collection and interpretation; writing. Sarah Elena Windolph: conception of the research approach; data collection and interpretation; writing. Jacob Hörisch: data analysis and interpretation; writing.

\section{Conflict of Interest}

The authors declare no conflict of interest.

\section{References and Notes}

1. Shrivastava, P. The role of corporations in achieving ecological sustainability. Acad. Manag. Rev. 1995, 20, 936-960.

2. Banerjee, S.B. Managerial Perceptions of Corporate Environmentalism: Interpretations from Industry and Implications for Organizations. J. Manag. Stud. 2001, 38, 489-513.

3. World Business Council for Sustainable Development (WBCSD). The business case for sustainable development: Making a difference towards the Earth Summit 2002 and beyond. Corp. Environ. Strategy 2002, 9, 226-235.

4. BMU German Federal Ministry for the Environment and Federation of German Industries, Ed. Sustainability Management in Business Enterprises. Concepts and Instruments for Sustainable Development; BMU/Centre for Sustainability Management (CSM): Berlin/Lueneburg, Germany, 2003.

5. Burger, P.; Daub, C.-H.; Scherrer, Y. New Perspectives on Sustainable Business (Editorial). J. Bus. Ethics 2009, 85, 479-481.

6. Marcus, J.; Kurucz, E.C.; Colbert, B.A. Conceptions of the Business-Society-Nature Interface: Implications for Management Scholarship. Bus. Soc. 2010, 49, 402-438.

7. Carter, C.R.; Dresner, M. Purchasing's Role in Environmental Management: Cross-Functional Development of Grounded Theory. J. Supply Chain Manag. 2001, 37, 12-27. 
8. Darnall, N.; Jolley, G.J.; Handfield, R. Environmental Management Systems and Green Supply Chain Management: Complements for Sustainability? Bus. Strategy Environ. 2008, 17, 30-45.

9. Seuring, S.; Müller, M. From a Literature Review to a Conceptual Framework for Sustainable Supply Chain Management. J. Clean. Prod. 2008, 16, 1699-1710.

10. Shrivastava, P.; Hart, S. Creating sustainable corporations. Bus. Strategy Environ.1995, 4, 154-165.

11. Dunphy, D.; Griffiths, A.; Benn, S. Organizational Change for Corporate Sustainability: A Guide for Leaders and Change Agents of the Future, 2nd ed.; Routledge: London, UK, 2007.

12. Martin, A.; Benn, S.; Dunphy, D. Towards a model of governance for sustainability. In Corporate Governance and Sustainability: Challenges for Theory and Practice; Benn, S., Dunphy, D., Eds.; Routledge: London, UK, 2007; pp. 94-121.

13. Epstein, M.J. Making Sustainability Work: Best Practices in Managing and Measuring Corporate Social, Environmental and Economic Impacts; Greenleaf: San Francisco, USA, 2008; pp. 90-93.

14. Porter, M.E. Competitive Advantage: Creating and Sustaining Superior Performance; Free Press: New York, NY, USA, 1985.

15. Carter, C.R.; Rogers, D.S. A framework of sustainable supply chain management: Moving toward new theory. Int. J. Phys. Distr. Log. 2008, 38, 360-387.

16. Singh, R.K.; Murty, H.R.; Gupta, S.K.; Dikshit, A.K. Integrated environment management in steel industries. Inter. J. Manag. Decis. Mak. 2008, 9, 103-128.

17. Gattiker, T.F.; Carter, C.R. Understanding Project Champions' Ability to Gain Intra-organizational Commitment for Environmental Projects. J. Oper. Manag. 2010, 28, 72-85.

18. Schmidt, I.; Meurer, M.; Saling, P.; Kicherer, A.; Reuter, W.; Gensch, C.-O. SEEbalance. Greener Manag. Int. 2004, 45, 79-94.

19. Schaltegger, S.; Burritt, R. Corporate Sustainability. In The International Yearbook of Environmental and Resource Economics; Folmer, H., Tietenberg, T., Eds.; Elgar: Cheltenham, UK, 2005; pp. 185-232

20. Nijhof, A.; de Bruijn, T.; Honders, H. Partnerships for corporate social responsibility: A review of concepts and strategic options. Manag. Decis. 2008, 46, 152-167.

21. Voiculescu, A. Challenges and innovation in the legal discourse: Achieving corporate responsibility for human rights. Soc. Bus. Rev. 2011, 6, 278-291.

22. Hanna, M.D.; Newman, W.R.; Johnson, P. Linking operational and environmental improvement through employee involvement. Int. J. Oper. Prod. Manag. 2000, 20, 148-165.

23. Nikolaou, I.E.; Evangelinos, K.I. Towards a generally accepted CSR accounting framework: A literature mapping. World Rev. Entrepren. Manag. Sustain. Dev. 2009, 5, 26-41.

24. Hansen, F. Hemispheral Lateralization: Implication for Understanding Consumer Behavior. J. Consum. Res. 1981, 8, 23-36.

25. Hemetsberger, A.; Pieters, R. When Consumers Produce on the Internet: An Inquiry into Motivational Sources of Contribution to Joint Innovation. In Proceedings of the Fourth International Research Seminar on Marketing Communications and Consumer Behavior, La Londe, France, 2001; Derbaix, C., Kahle, L.R., Merunka, D., Strazzieri, A., Eds.; pp. 274-291.

26. Veleva, V.; Ellenbecker, M. Indicators of Sustainable Production: Framework and Methodology. J. Clean. Prod. 2001, 9, 519-549. 
27. Frondel, M.; Horbach, J.; Rennings, K. What triggers environmental management and innovation? Empirical evidence for Germany. Ecol. Econ. 2008, 66, 153-160.

28. Kotler, P.; Nancy, L. Corporate Social Responsibility: Doing the Most Good for Your Company and Your Cause; Wiley: New York, NY, USA, 2004.

29. Belz, F.-M.; Peattie, K. Sustainability Marketing: A Global Perspective, 2nd ed.; Wiley: Chichester, UK, 2012.

30. Hart, S.L. Beyond greening. Strategies for a sustainable world. Harvard Bus. Rev. 1997, 75, 66-76.

31. Prahalad, C.K.; Hart, S.L. The fortune at the bottom of the pyramid. Strat. Bus. 2002, 26, 1-14.

32. Hansen, E.G.; Grosse-Dunker, F.; Reichwald, R. Sustainability Innovation Cube-A Framework To Evaluate Sustainability-Oriented Innovations. Int. J. Innov. Manag. 2009, 13, 683-713.

33. Oglethorpe, D.; Heron, G. Sensible operational choices for the climate change agenda. Int. J. Logist. Manag. 2010, 21, 538-557.

34. Wagner, M. Integration of Environmental Management with Other Managerial Functions of the Firm. Empirical Effects on Drivers of Economic Performance. Long Range Plann. 2007, 40, 611-628.

35. Clark, C.E. Differences between public relations and corporate social responsibility: An analysis. Public Relat. Rev. 2000, 26, 363-380.

36. Black, L.D.; Härtel, C.E.J. The five capabilities of socially responsible companies. J. Publ. Aff. 2004, 4, 125-144.

37. Daily, B.F.; Huang, S. Achieving sustainability through attention to human resource factors in environmental management. Int. J. Oper. Prod. Manag. 2001, 21, 1539-1552.

38. Ehnert, I. Sustainable Human Resource Management: A Conceptual and Exploratory Analysis from a Paradox Perspective; Physica: Berlin/Heidelberg, Germany, 2009.

39. Schaltegger, S.; Burritt, R. Contemporary Environmental Accounting: Issues, Concepts and Practice; Greenleaf: Sheffield, UK, 2000.

40. Burritt, R.; Hahn, T.; Schaltegger, S. Towards a Comprehensive Framework for Environmental Management Accounting. Links Between Business Actors and Environmental Management Accounting Tools. Aust. Account. Rev. 2002, 12, 39-50.

41. Henri, J.-F.; Journeault, M. Eco-control: The Influence of Management Control Systems on Environmental and Economic Performance. Account. Organ. Soc. 2010, 35, 63-80.

42. Lawrence, P.R.; Lorsch, J.W. Differentiation and Integration in Complex Organizations. Admin. Sci. Quart. 1967, 12, 1-47.

43. Hoffman, A.J. Linking Organizational and Field-Level Analyses: The Diffusion of Corporate Environmental Practice. Organ. Environ. 2001, 14, 133-156.

44. Schein, E.H. Organizational Culture and Leadership; Wiley: San Francisco, CA, USA, 2010.

45. Schaltegger, S.; Harms, D.; Windolph, S.E. Who is involved?-Integrating corporate functions into sustainability management. In Proceedings of the 13th EURAM conference 2013, Istanbul, Turkey, 26-29 June 2013.

46. Houston, M.J.; Rothschild, M.L. Conceptual and Methodological Perspectives on Involvement. In Research frontiers in Marketing Dialogues and Directions; Jain, S.C., Ed.; American Marketing Association: Chicago, IL, USA, 1978; pp. 184-187. 
47. Lorenzoni, I.; Nicholson-Cole, S.; Whitmarsh, L. Barriers perceived to engaging with climate change among the UK public and their policy implications. Global Environ. Change 2007, 17, 445-459.

48. Roome, N. Business Strategy, R\&D Management and Environmental Imperatives. R\&D Manag. 1994, 24, 65-82.

49. Speis, H.; Czymmek, F. Die Bedeutung der ökologischen Betroffenheit für die um-weltschutzorientierten Wettbewerbsstrategien von Unternehmen; Arbeitsberichte zum Umweltmanagement, Arbeitsbericht Nr. 15; Universität zu Köln: Köln, Germany, 2003. (In German)

50. Altholz, V. The advantages and limitations of developing an external perspective for analyzing corporate strategic alignment. Econ.Environ. Stud. 2010, 10, 35-48.

51. Freeman, R.E. Strategic Management: A Stakeholder Approach; Pitman: Boston, MA, USA, 1984.

52. DiMaggio, P.J.; Powell, W.W. The Iron Cage Revisited: Institutional Isomorphism and Collective Rationality in Organizational Fields. Am. Sociol. Rev. 1983, 48, 147-160.

53. Bansal, P.; Roth, K. Why companies go green: A model of ecological responsiveness. Acad. Manag. J. 2000, 43, 717-736.

54. Marais, M. CEO rhetorical strategies for corporate social responsibility (CSR). Soc. Bus. Rev. 2012, 7, 223-243.

55. Hahn, T.; Scheermesser, M. Approaches to corporate sustainability among German companies. Corp. Soc. Resp. Environ. Manag. 2006, 13, 150-165.

56. Schaltegger, S. Sustainability as a Driver for Corporate Economic Success: Consequences for the Development of Sustainability Management Control. Soc. Econ.2011, 33, 15-28.

57. Abrahamson, E. Managerial Fads and Fashions: The Diffusion and Rejection of Innovations. Acad. Manag. Rev. 1991, 16, 586-612.

58. Abrahamson, E.; Fairchild, G. Management fashion: Lifecycles, triggers, and collective learning processes. Admin. Sci. Quart. 1999, 44, 708-740.

59. Tencati, A.; Perrini, F.; Pogutz, S. New Tools to Foster Corporate Socially Responsible Behavior. J. Bus. Ethics 2004, 53, 173-190.

60. Schaltegger, S.; Hörisch, J.; Herzig, C. Methodische Operationalisierung unternehmerischer Nachhaltigkeit. Methodenbekanntheit, -anwendung und förderpolitische Implikationen. Zeitschrift für Umweltpolitik und Umweltrecht 2013, 1, 87-115. (In German)

61. Schaltegger, S.; Burritt, R.; Petersen, H. An Introduction to Corporate Environmental Management: Striving for Sustainability; Greenleaf: Sheffield, UK, 2003.

62. Herzig, C.; Schaltegger, S. Corporate Sustainability Reporting. In Sustainability Communication. Interdisciplinary Perspectives and Theoretical Foundations; Godemann, J., Michelsen, G., Eds.; Springer: Dordrecht, The Netherlands, 2011; pp. 151-170.

63. Sharma, S.; Henriques, I. Stakeholder influences on sustainability practices in the Canadian forest products industry. Strategy Manag. J. 2005, 26, 159-180.

64. Gallo, P.J.; Christensen, L.J. Firm Size Matters: An Empirical Investigation of Organizational Size and Ownership on Sustainability-Related Behaviors. Bus. Soc. 2011, 50, 315-349.

65. Brammer, S.J.; Pavelin, S. Corporate Reputation and Social Performance: The Importance of Fit. J. Manag. Stud. 2006, 43, 435-455. 
66. Darnall, N.; Henriques, I.; Sadorsky, P. Adopting Proactive Environmental Strategy: The Influence of Stakeholders and Firm Size. J. Manag. Stud. 2010, 47, 1072-1094.

67. Esrock, S.L.; Leichty, G.B. Social responsibility and corporate web pages: Self-presentation or agenda-setting? Public Relat. Rev. 1998, 24, 305-319.

68. Shah, K.U. Corporate Environmentalism in a Small Emerging Economy: Stakeholder Perceptions and the Influence of Firm Characteristics. Corp. Soc. Responsib. Environ. Manag. 2011, 18, 80-90.

69. Knoepfel, I. Dow Jones Sustainability Group Index: A Global Benchmark for Corporate Sustainability. Corp. Environ. Strategy 2001, 8, 6-15.

70. Fowler, S.J.; Hope, C. A Critical Review of Sustainable Business Indices and their Impact. J. Bus. Ethics 2007, 76, 243-252.

71. Consolandi, C.; Jaiswal-Dale, A.; Poggiani, E.; Vercelli, A. Global Standards and Ethical Stock Indexes: The Case of the Dow Jones Sustainability Stoxx Index. J. Bus. Ethics 2009, 87, 185-197.

72. Die 500 größten Unternehmen in Deutschland. Available online: http://top500.welt.de (accessed on 13 July 2009). (In German)

73. Marsden, C. The New Corporate Citizenship of Big Business: Part of the Solution to Sustainability? Bus. Soc. Rev. 2000, 105, 8-25.

74. Lewis, G.J.; Harvey, B. Perceived Environmental Uncertainty: The Extension of Miller's Scale to the Natural Environment. J. Manag. Stud. 2001, 38, 201-233.

75. Brammer, S.J.; Pavelin, S.; Porter, L.A. Corporate Charitable Giving, Multinational Companies and Countries of Concern. J. Manag. Stud. 2009, 46, 575-596.

76. Estrin, S.; Baghdasaryan, D.; Meyer. K.E. The Impact of Institutional and Human Resource Distance on International Entry Strategies. J. Manag. Stud. 2009, 46, 1171-1196.

77. Muller, A.; Kolk, A. Extrinsic and Intrinsic Drivers of Corporate Social Performance: Evidence from Foreign and Domestic Firms in Mexico. J. Manag. Stud. 2010, 47, 1-26.

78. Carter, C.R.; Jennings, M.M. The Role of Purchasing in Corporate Social Responsibility: A Structural Equation Analysis. J. Bus. Logist. 2004, 25, 145-186.

79. Deutsche Börse 2010. Available online: http://www.dax-indices.com/EN/index.aspx?pageID=4 (accessed 4 February 2010).

80. Ebsco. Available online: www.ebsco.com (accessed on 29 August 2012).

81. Web of Science. Available online: www.webofknowledge.com (accessed on 29 August 2012).

82. Backhaus, K.; Erichson, B.; Plinke, W.; Weiber, R. Multivariate Analysemethoden: Eine anwendungsorientierte Einführung, 11th ed.; Springer: Berlin/Heidelberg, Germany, 2011. (In German)

83. Hunting, S.A.; Tilbury, D. Shifting towards Sustainability: Six Insights into Successful Organisational Change for Sustainability; The Australian Research Institute for Environment and Sustainability: Sydney, Australia, 2006.

(C) 2014 by the authors; licensee MDPI, Basel, Switzerland. This article is an open access article distributed under the terms and conditions of the Creative Commons Attribution license (http://creativecommons.org/licenses/by/3.0/). 